\title{
Seven Cases of Wart treated with MY1-Hwan
}

\author{
Ah-Ra Cho, San Seo, Yoon-Hong Yang, A-Rin Lee, Hyung-Tak Lee \\ Freehug Korean Medicine Clinic
}

Objectives: The purpose of this study is to report effectiveness of MY1-Hwan(MYH) on wart patients.

Methods: Seven wart patients who wanted to treat wart with Korean medicine took MYH $2 \sim 3$ times a day for $2 \sim 4$ months without external treatments.

Results: Nodules or papules of wart were vanished from seven patients' lesion. Specific side effect was not shown. Conclusions: MYH was effective to treat seven wart cases. However, seven cases are not enough to figure out the various effects of MYH and the effectiveness on other kind of wart. So follow-up studies are needed based on this study.

Key Words : Wart, Korean Medicine, MY1-HWan

\section{Introduction}

Wart is a kind of dermatopathy infected with human papilloma virus (HPV) on the epidermis. HPV is classified into different genotypes by DNA sequence. And then wart is classified by the genotype of HPV ${ }^{1)}$. Sometimes wart is treated naturally without any treatments. Otherwise, the wart can make the appearance less attractive and others infected. Even some wart patients feel a severe pain according to the skin lesion. So there is relatively high expectation to treat wart among the patients ${ }^{2)}$.

Surgical procedures such as cryotherapy, laser therapy, and electric cauterization are generally used for treating wart in a dermatology clinic. However, these surgical procedures can leave a scar on the skin and make the patient painful during the procedure. And the ratio of wart recurrence is high after a surgical procedure ${ }^{2-4)}$. Some patients want to treat their wart with Korean medicine because they worry about the pain and recurrence after a surgical procedure.

In Korean medicine, the wart is treated mostly with herbal medicine and additionally with some external treatments such as acupuncture, moxibustion and herbal acupuncture therapy ${ }^{5)}$. However, wart patients should visit the clinic regularly to get external treatments more than 20 times in some cases ${ }^{5,6}$, so some patients can feel hard to visit regularly for many reasons, for example, the clinic is far from their place or they can not afford their time off work. In addition, if there are many small papules on the wart skin, a doctor is hard to do external treatment one by one. So if it is possible to treat wart with herbal medicine without the external treatments, it is expected that the patients can get treated more

\footnotetext{
- Received : 6 December 2018 - Revised : 13 December 2018 -Accepted : 17 December 2018

- Correspondence to : Ahra Cho

\#1203 Downtown Bldg. 97 Baekhyun-ro Bundang-gu Seongnam-si Gyeonggi-do, Republic of Korea

Tel : 031-715-8269, Fax : 031-715-8260, E-mail :freehug_bd@naver.com
} 
conveniently and the doctors can treat wart efficiently.

However, it is hard to find a study of Korean medicine treatment without any external treatments. So we made a new herbal medicine named as MY1-Hwan(MYH) to treat wart and prescribed that for wart patients without external treatments. In this report, seven cases show significant results of MYH to treat the wart.

\section{Cases}

\section{Patients}

Patient 1

Name : Kang ००

Imp.) Common wart

Gender/Age : F/15

O/S : since Dec. 2015

C/C : Rt. $1^{\text {st }}, 2^{\text {nd }}$ toes with nodules and papules

$\mathrm{P} / \mathrm{H}$ : Athlete's foot

$\mathrm{F} / \mathrm{H}$ : none specific

The period of treatment : Jul. $25^{\text {th }} 2016 \sim$ Sep. $29^{\text {th }}$ 2016

History of Present illness : Living in Jeju island. At initial, she got cryotherapy at local dermatology clinic. After 1 month later, wart reoccurred. Her parents wanted to treat wart with Korean medicine, so they visit our clinic. They can't visit clinic regularly because of such a long distance between clinic and their place.

\section{Patient 2}

Name : Oh o०

Imp.) Plantar wart

Gender/Age : F/21

$\mathrm{O} / \mathrm{S}$ : since 2008

$\mathrm{C} / \mathrm{C}$ : Rt. sole around $1^{\text {st }}$ toe. painful while walking

$\mathrm{P} / \mathrm{H}$ : gastritis

$\mathrm{F} / \mathrm{H}$ : none specific

The period of treatment : Apr. $23^{\text {rd }} 2018 \sim$ Jul. $14^{\text {th }}$ 2018
History of Present illness : since first occurrence of wart, she has got diverse treatments - cryotherapy, laser therapy, a folk remedy and etc. But wart reoccurred in at least 4 weeks later.

\section{Patient 3}

Name : Ahn o०

Imp.) Common wart and plantar wart

Gender/Age : M/31

$\mathrm{O} / \mathrm{S}$ : since 2014

$\mathrm{C} / \mathrm{C}:$ Rt. $2^{\text {nd }}, 3^{\text {rd }}$ fingers, Both soles with nodules and papules,

$\mathrm{P} / \mathrm{H}$ : Plantar wart on left sole (2008)

$\mathrm{F} / \mathrm{H}$ : none specific

The period of treatment : May. $14^{\text {th }} 2018 \sim$ Aug. $23^{\text {rd }} 2018$

History of Present illness : When he was in military service, first wart occurred and was treated at military hospital with cryotherapy. 4 years ago, wart reoccurred and was worse than the first. He has got laser therapy frequently, but wart was not treated. So he comes to get treated with Korean medicine.

\section{Patient 4}

Name : Park ००

Imp.) Plantar wart

Gender/Age : F/20

$\mathrm{O} / \mathrm{S}$ : since 2016

$\mathrm{C} / \mathrm{C}$ : Rt. sole

$\mathrm{P} / \mathrm{H}$ : constipation

$\mathrm{F} / \mathrm{H}:$ none specific

The period of treatment : Jul. $23^{\text {rd }} 2018 \sim$ Sep. $4^{\text {th }}$ 2018

History of Present illness : After first occurrence, she had got laser therapy every 2 weeks for a year. But wart had reoccurred every time, she gave up treating because of the pain during laser therapy. She wants to get painless treatment. 
Patient 5

Name : Seo oo

Imp.) Plantar wart

Gender/Age : M/11

$\mathrm{O} / \mathrm{S}:$ since 2017

$\mathrm{C} / \mathrm{C}$ : Lt. sole

$\mathrm{P} / \mathrm{H}$ : Molluscum contagiosum (2013)

$\mathrm{F} / \mathrm{H}$ : none specific

The period of treatment : Jan. $13^{\text {th }} 2018 \sim$ May. $19^{\text {th }} 2018$

History of Present illness : 5 years ago, molluscum contagiosum occurred on his abdomen and was treated naturally. 1 year ago, his parents found his wart and they thought it was also able to be treated naturally. But wart was not treated naturally, and even he was getting more painful because of wart. He doesn't have any wart treatments before.

\section{Patient 6}

Name : Kim ○०

Imp.) Common wart

Gender/Age : F/50

$\mathrm{O} / \mathrm{S}$ : since Jan. 2018

$\mathrm{C} / \mathrm{C}$ : Lt. $1^{\text {st }} 2^{\text {nd }}$ fingers, Rt. $2^{\text {nd }} 3^{\text {rd }}$ fingers with nodules and papules

$\mathrm{P} / \mathrm{H}$ : none specific

$\mathrm{F} / \mathrm{H}$ : none specific

The period of treatment : Jul. $17^{\text {th }} 2018 \sim$ Aug. $25^{\text {th }}$ 2018

History of Present illness : She could not get a surgical therapy because she is working in a fish market. She wants to treat her wart with only taking a medicine.

\section{Patient 7}

Name : Kang oo

Imp.) Common wart

Gender/Age : M/23

O/S : since Feb. 2018
$\mathrm{C} / \mathrm{C}:$ Rt. $4^{\text {th }}$ finger with nodule

$\mathrm{P} / \mathrm{H}$ : none specific

$\mathrm{F} / \mathrm{H}$ : none specific

The period of treatment : Aug. $24^{\text {th }} 2018 \sim$ Nov. $27^{\text {th }}$ 2018

History of Present illness : First occurrence was in Feb. 2018. He got a laser therapy just after aware of his wart. But wart was not treated and he thought his wart was impossible to be treated. A few days ago, one of his friend recommended Korean medicine to treat wart.

\section{Treatment}

MYH contains seven herbs (Table 1). All herbs were ground to powder for the size of 200 mesh. The pure water which weighed as $20 \%$ of total herb weight was added to the powder. Then the pill of $4 \mathrm{~mm}$ diameters was made from the water added powder and then dehydrated to make MYH with no additive material. Seven wart patients took $6 \mathrm{~g}$ of MYH 2 3 times a day.

Table 1. Composition of MY1-Hwan

\begin{tabular}{ccc}
\hline Herb & Scientific Name & Dose $(\mathrm{g})$ \\
\hline 薏药仁 & Coicis Semen & 40 \\
杜仲 & Eucommiae Cortex & 20 \\
桑白皮 & Mori Cortex & 18 \\
薑黃 & Curcumae Longae Rhizoma & 18 \\
獨活 & Araliae Continentalis Radix & 18 \\
紫蘇葉 & Perillae Folium & 18 \\
五加皮 & Acanthopanacis Cortex & 10 \\
\hline
\end{tabular}

\section{Diagnosis and Assessment}

Wart can be diagnosed by clinical manifestation. Various size of papules are observed in common wart. Squashed nodules or papules are observed in plantar wart and the patients complain of pain while they are walking ${ }^{7)}$.

The patients' lesions were taken a photo at their first visit with Nikon ${ }^{\circledR}$ D80. The end of treatment was decided when the lesion was improved completely 
with naked doctor's eye, and the patient did not feel any subjective symptoms. If the patient was a minor under age of 19, patient's legal guardian got informed about the patient's improvement from the doctor, and then the end of treatment was decided under the guardian's agreement. At the end of treatment, the lesion was also taken a photo for recording improvement.
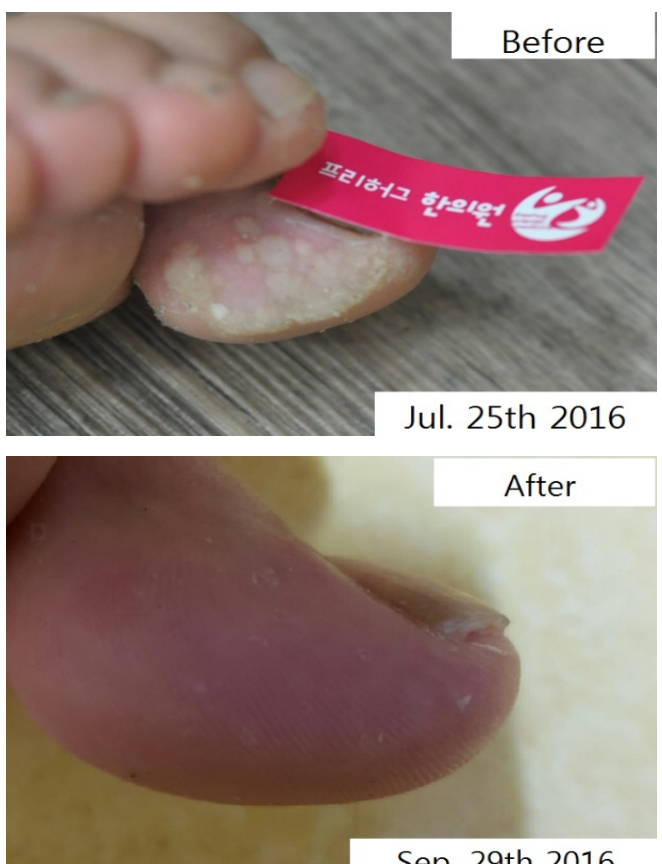

Sep. 29th 2016

Fig 1. The Result of Patient 1

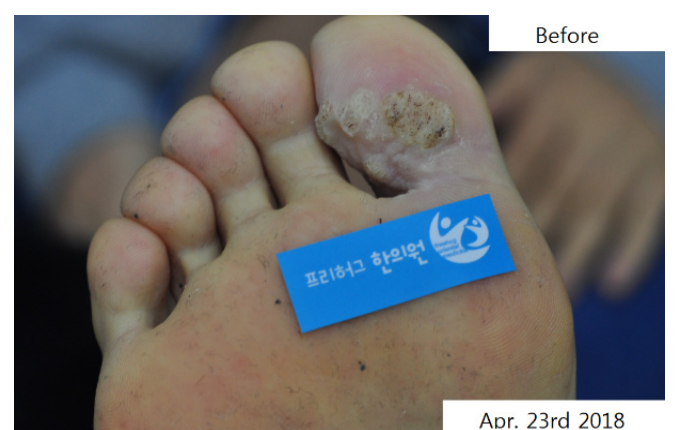

Fig 2. The Result of Patient 2

\section{Ethic}

This study was conducted with the consent of the patients to collect medical information after explaining this study.

\section{Results}

The results of seven wart patients were attached to Fig. 1 Fig. 7 .
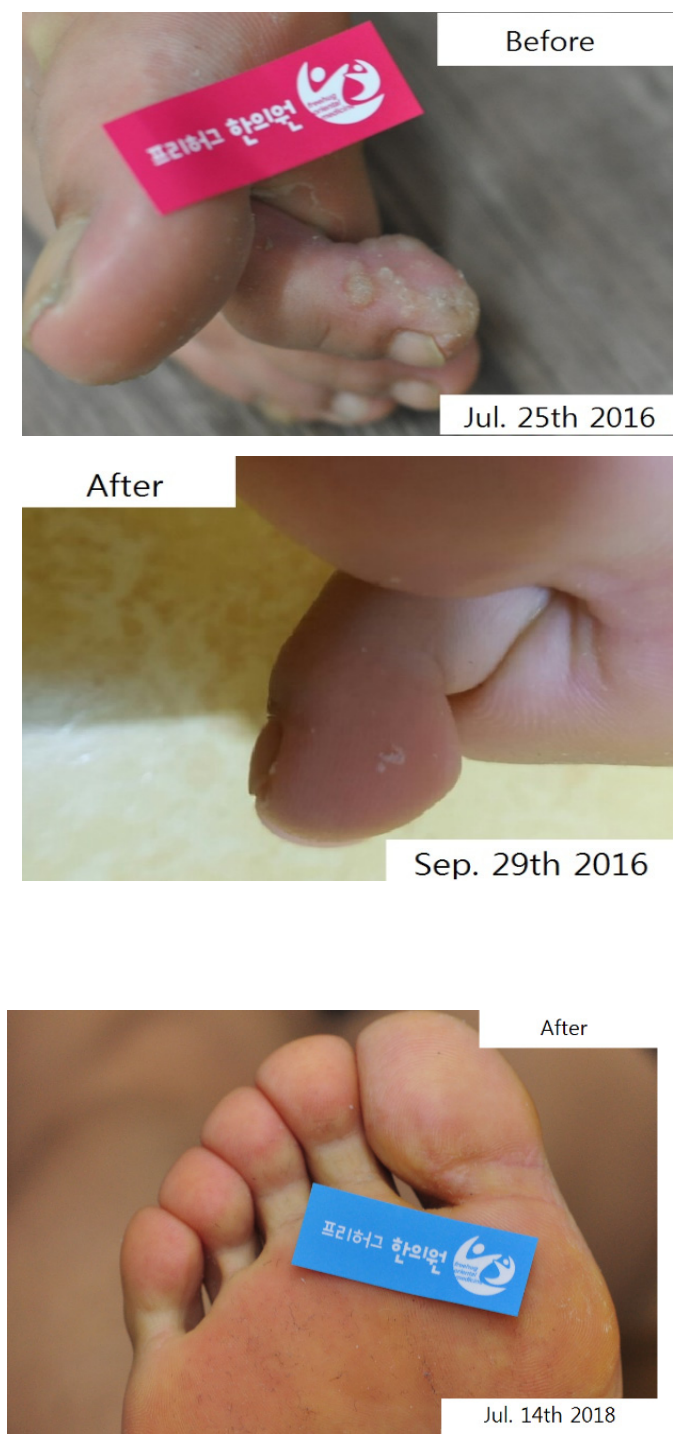

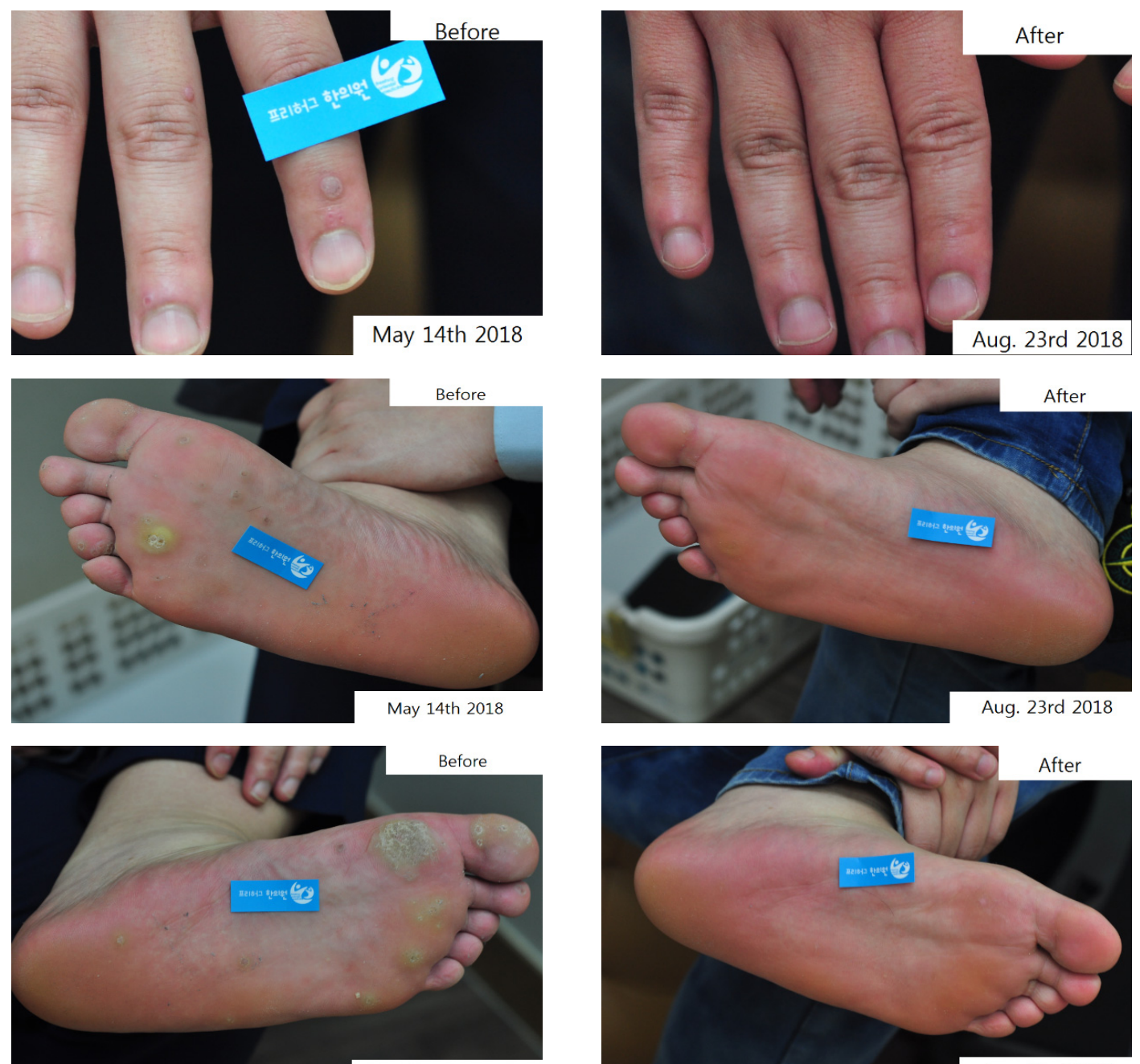

May 14th 2018

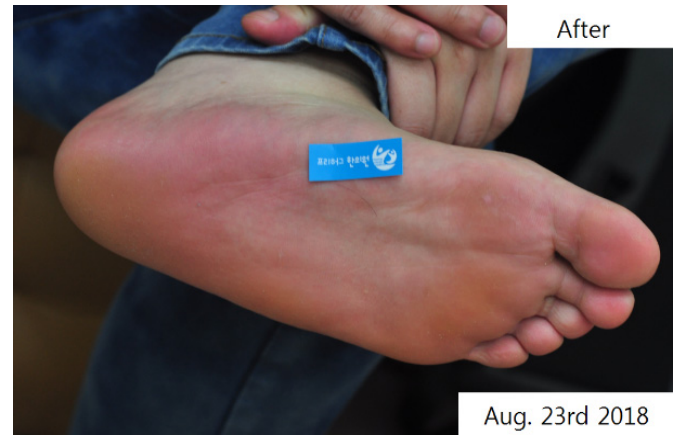

Fig 3. The Result of Patient 3
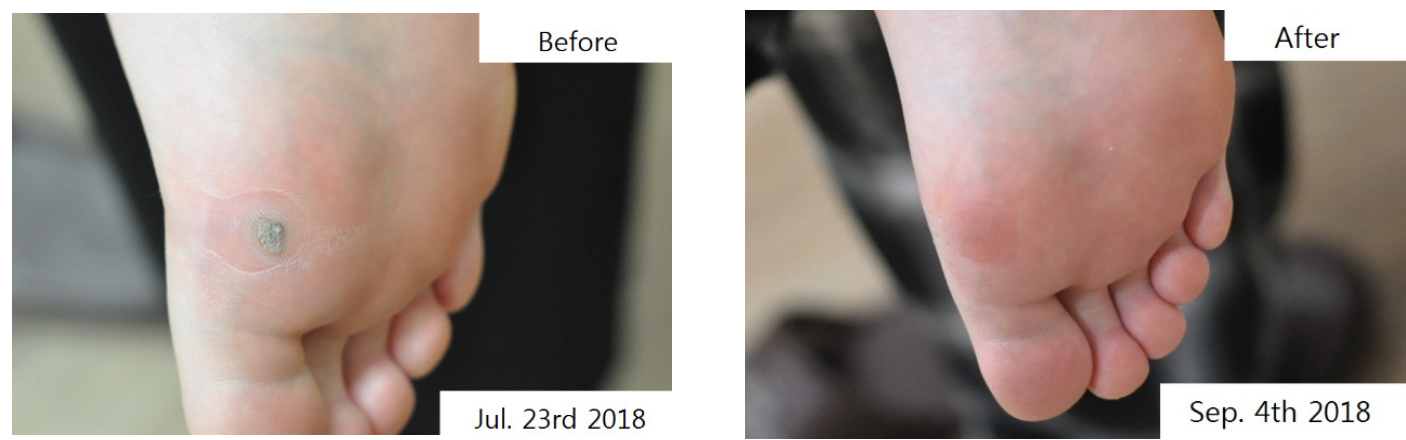

Fig 4. The Result of Patient 4 
Journal of Korean Medicine 2018;39(4)
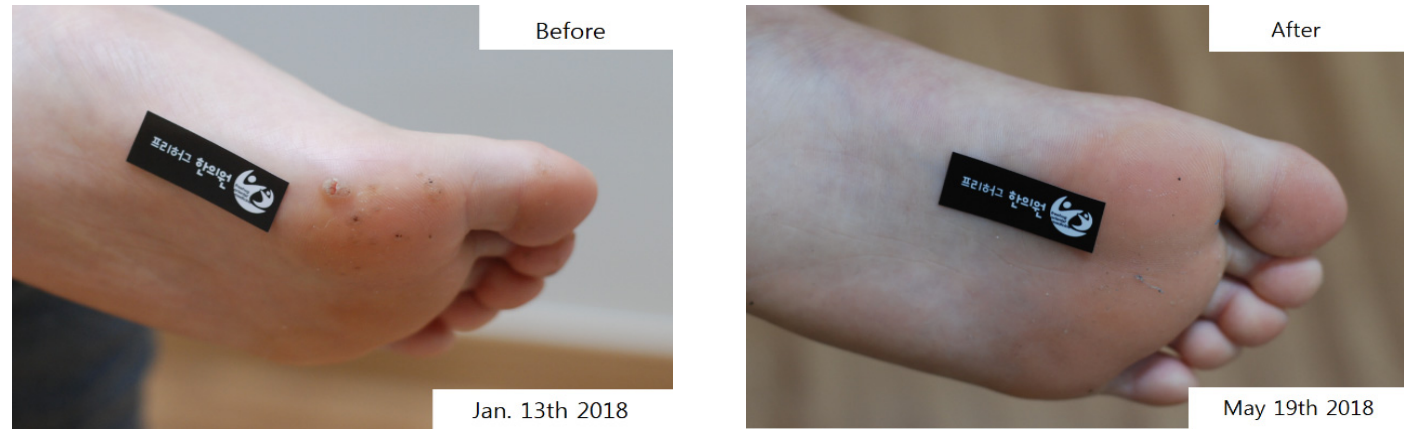

Fig 5. The Result of Patient 5
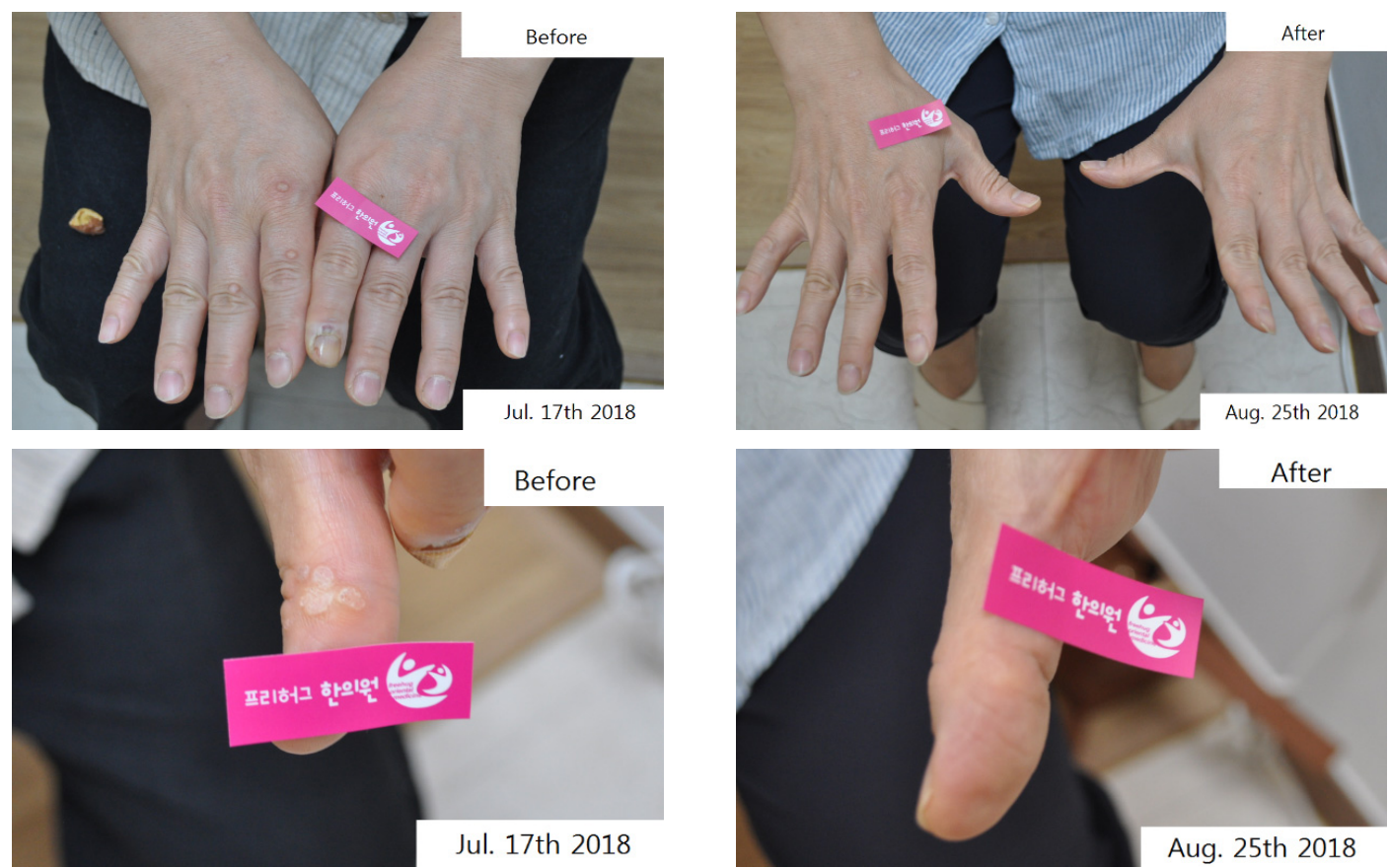

Fig 6. The Result of Patient 6
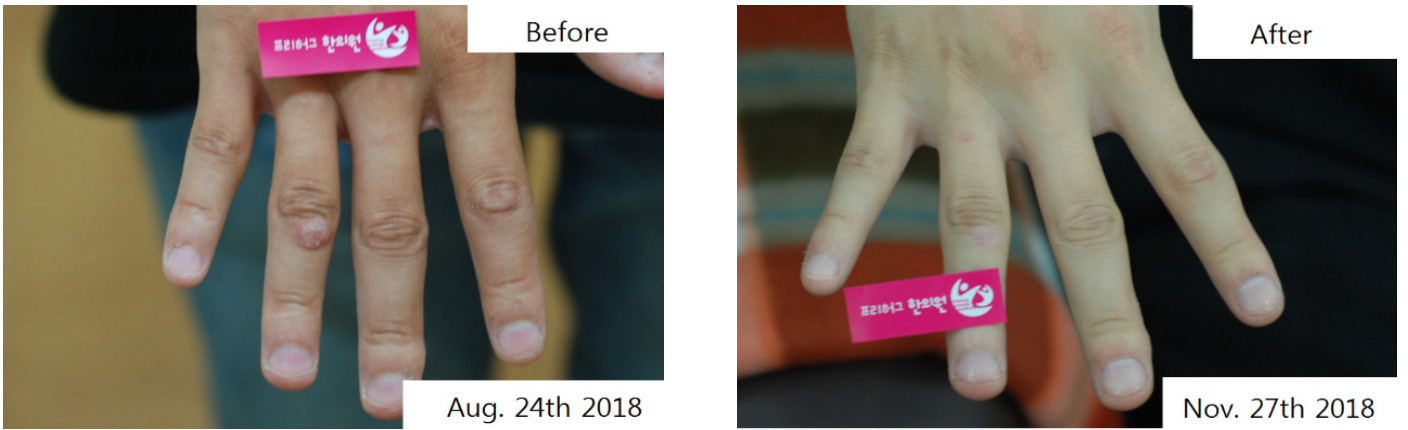

Fig 7. The Result of Patient 7 


\section{Discussion and Conclusion}

Wart is a kind of common infectious disease from human papilloma virus (HPV). Wart is classified according to clinical aspect as a common wart, flat wart, plantar wart, and genital wart. Recently the genotype of each wart was discovered. Common wart and plantar wart mostly occurs by HPV-1, 2, 4, 57 and flat wart occurs by HPV-3, $10^{1}$. The treatment of different wart is not different according to different genotype. In modern medicine, cryotherapy, laser therapy, etc. are used to treat wart regardless of genotype. But because of the high ratio of wart recurrence after these therapy and the pain during the treatment, some wart patients are looking for the other way of wart treatment. In Korean medicine, herbal medicine, acupuncture, moxibustion, and herbal acupuncture are typically used to treat the wart. External therapies, like herbal acupuncture and moxibustion, should be conducted regularly in Korean medicine clinic. However, some wart patients can not visit the clinic regularly for many reasons. If possible, taking herbal medicine without external therapies can make patients convenient no need to visit clinic frequently. Therefore, MY1-Hwan (MYH) was made to treat wart without therapies.

Previously some researches were conducted to treat wart in Korean medicine. Gwakhyangjeongki-san (Huoxiangzhengqi-san) and Eejin-tang(Erchen-tang) were mainly used to treat the wart, and acupuncture or moxibustion was prescribed along with the medicine ${ }^{8)}$. In Korean medicine, the wart is related to the liver, so it occurs when the liver blood gets damaged, or liver fire is excessive. Therefore, a common way of Korean medicine to treat wart is clearing heat, resolving toxicity and calming the liver ${ }^{9)}$. However, it was hard to observe passage after prescribing same medicine to diverse wart patients because the way of treating wart was not standardized. Therefore, MYH was made to prescribe effective same Korean medicine to diverse wart patients without adding or subtracting herbs.

Coicis Semen is the highest percentage of MYH. Coicis Semen already has been used to treat wart ${ }^{9)}$. Coicis Semen was known to influence cellular immunity for treating infectious disease and viral disease $\mathrm{e}^{10-12)}$. As a simple prescription, Coicis Semen was reported to be possible to treat wart ${ }^{13)}$. Therefore Coicis Semen is an essential herb to treat the wart. In this report, Coicis Semen was also used as a primary herb to consist of MYH.

In Korean medicine Eucommiae Cortex has tonified the liver and the kidney, made body comfortable and has an anti-aging effect ${ }^{14)}$. Eucommiae Cortex was also known to increase collagenesis, to suppress tumorous proliferation and to improve immune ability ${ }^{15-17)}$. These effects of Eucommiae Cortex are expected to improve recovering the damaged skin and suppress spreading HPV.

Mori Cortex was written in Donguibogam that it had effects of treating a cough and epistaxis ${ }^{18)}$. Additionally, Mori Cortex was studied for using its pharmacological effects because it had anti-inflammation, anti-tumor and skin anti-aging effect $^{19,20)}$. Mori Cortex also had an antiviral effect ${ }^{21)}$. Thus Mori Cortex can help to treat wart which is one of the viral diseases.

One of the medicinal agents in Curcumae Longae Rhizoma is curcumin ${ }^{14)}$. Curcumin was reported about its antiviral of HPV what is the cause of wart ${ }^{22)}$. Still, many studies focused on how curcumin affected HPV related to cervical cancer. However, HPV has the same L1 capsid protein regardless of different genotypes ${ }^{23}$. So curcumin is inferred that it induces an antiviral effect on diverse genotypes of HPV not only related to cervical cancer but also wart. 
Araliae Continentalis Radix inhibits generating free radical NO which induces tissue damage and abnormal immune system ${ }^{24}$. Pathologically free radical NO makes capillaries spread to a lesion. The lesion of wart is observed that the capillaries spread. So Araliae Continenetalis Radix can be expected to inhibit spreading capillaries to wart in the process of inhibiting free radical NO and to contribute to treating the wart.

Also, Perillae Folium can activate innate and acquired immunity ${ }^{25)}$. Thus it is useful to treat wart which is an infectious viral disease. Acanthopanacis Cortex was known experimentally to protect liver tissues ${ }^{26)}$ and it can prevent liver tissue damage from long-term taking MYH.

MYH is composed of these seven herbs. Even though MYH is a totally new herbal medicine which was never studied before, it is expected that the interaction of seven herbs can get rid of HPV from the lesion, recover damaged skin and prevent reoccurrence of wart.

In this study, all seven patients had a common wart or plantar wart. It took 2 4 months to get improved. It was entirely different from previous studies that only herbal medicine MYH was prescribed without any external treatments to all wart patients. There were no particular complaints except that some patients felt hard to swallow MYH. Specific side effect was not shown to all patients. Unfortunately, hepatotoxicity and nephrotoxicity were not checked because the test equipments were not prepared.

In this study all seven patients had a common wart or plantar wart. So more cases are needed to figure out how effective MYH to diverse wart patients, for example, genital wart or flat wart. In addition, seven cases were not enough to check carefully the various effects of MYH including side effect. If possible, it would be more useful to conduct additional larger clinical study for analyzing the effects of MYH. Moreover, it would be better to have a chance to conduct a molecular biological study for supposing how MYH works. Finally, the seven patients will be checked that wart recurs or not after stop taking MYH.

This study is significant because it showed that new herbal medicine was effective to treat the wart although it had some limits and lacks without advanced studies. However, it is expected that additional follow-up study will be able to supplement limits and lacks gradually. Trying to make a new herbal medicine like MYH is thought as a way of contributing to the development of future Korean medicine. Seven case was not enough to prove the effect of MYH completely, but we wish more studies about MYH will be conducted based on this study.

\section{References}

1. Sterling JC, Handfield-Jones S, Hudson PM. Guidelines for the management of cutaneous warts. Br J Dermatol. 2001;144:4-11.

2. Horn TD, Johnson SM, Helm RM, Roberson PK. Intralesional immunotherapy of warts with mumps, Candida, and trichophyton skin test antigens: a single-blinded, randomized, and controlled trial. Arch Dermatol. 2005;141:589-94.

3. Clifton MM, Johnson SM, Roberson PK, Kincannon J, Horn TD. Immunotherapy for recalcitrant warts in children using intralesional mumps or candida antigens. Pediatr Dermatol. 2003;20:268-71.

4. Kim MB, Ko HC, Jang BS, Kwon YW, Oh CK, Jang HS, et al. The Effects of 5\% Imiquimod Cream on Verruca Plana. Korea J Dermatol. 2008;43(5):643-9.

5. Yun YH, Choi IW. A Case Report of Verruca Plana. J Korean Oriental Med. 2008;29(3):161-8.

6. Lee JH, Shim GS. Five Cases of Viral Warts Treated by Korean Medicine. J Korean Med Ophthalmol Otolaryngol Dermatol. 2015;28(3):121-129. 
7. Dermatology Textbook Compliation Committee. Dermatology. Seoul:Daehan Medical Books,2014:472-474.

8. Yun JM, Shin SH, Yoon HJ, Ko WS. A Statistical Study of Patients visited Wart Clinic. J Korean Med Ophthalmol Otolaryngol Dermatol. 2009;22(2):192-200.

9. College of Oriental Medicine Dermatology\&Surgery Textbook Compilation Committee. Text of Traditional Korean Dermatology\&Surgery. Busan:Sunwoo. 2007:432-8.

10. Hidaka Y, Kaneda T, Amino N, Miyaki K. Chinese medicine. Coix seeds increase peripheral cytotoxic T and NK cells. Biotherapy. 1992;5(3):201-3.

11. Kaneda T, Hidaka Y, Kashiwai T, Tada H, Takano $\mathrm{T}$, Nishiyama $\mathrm{S}$, et al. Effect of coix seed on the changes in peripheral lymphocyte subsets. Rinsho Byori. 1992;40(2):179-81.

12. Kim HC. Herbal Pharmacology. Paju:Jipmundang. 2008:227-9.

13. Jeong HY, Cho CS. A Clinical Report of the Effect of Uiin-san on a Wart Patient. J Int Korean Med. 2016;37(5):704-10.

14. College of Herbology Textbook Compilation Committee. Herbology. Seoul:Youngrimsa. 2004:457-8, 605-7.

15. Li Y, Kamo S, Metori K, Koike K, Che QM, Takahashi S. The promoting effect of eucommiol from Eucommiae cortex on collagen synthesis.

Biological and Pharmaceutical Bulletin. 2000;23(1):54-9.

16. Kim UJ, Kim SH. Effect of Eucommia Cortex and Eucommia Cortex Leaf on Immune Function. Journal of Herbology. 1994;9(1):99-113.

17. Kim JB, Park JR, Jeon JR, Cha MH. Isolation and Identification of Anticancer Compounds from Eucommia ulmoides Leaves. Journal of the Korean Society of Food Science and Nutrition. 2001;30(4):732-8.
18. Hur J. Dongeubogam. Seoul:Yeogang. 1994:2803-5.

19. Ko HH, Yu SM, Ko FN, Teng CM, Lin CN. Bioactive constituents of Morus australis and Broussonetia papyrifera. J Nat Prod. 1997;60: 1008-11.

20. Ni G, Zhang QJ, Wang YH, Chen RY, Zheng ZF, Yu DQ. Chemical constituents of the stem bark of Morus cathayana. J Asian Nat Prod Res. 2010;12:505-15.

21. Kwon DH, Kim MB, Yoon DY, Lee YH, Kim JW, Lee HG, et al. Screening of Plant Resources of Anti-viral Activity, Korean J Medicinal Crop Sci. 2003;11(1):24.

22. Teymouri M, Pirro M, Johnston T, Sahebkar A. Curcumin as a Multifaced Compound against Human Papilloma Virus Infection and Cervical Cancers: A Review of Chemistry, Cellular, Molecular, and Preclinical features. International Union of Biochemistry and Molecular Biology. 2017;43(3):331-46.

23. Chow LT, Broker TR. Small DNA tumor viruses, In: Nathanson N, Ahmed R, Gonzelez-Scarano F, editors. Viral pathogenesis. 1st ed. Philadelphia:Lippincott-Raven,1997:267-301.

24. Kang CH, Koo JR, So JS. Inhibitory Effects of Aralia cordata Thunb Extracts on Nitric Oxide Synthesis in RAW 264.7 Macrophage Cells. Korean J. Food Sci. Technol. 2012;44(5):621-7.

25. Byun EH. Immunomodulatory Activities of Crude Polysaccharide Fraction Separated fre Perilla frutescens Britton var. acuta Kudo. Korean J. Food Sci. Technol. 2017;49(5):559-66.

26. Cho JH, Park IJ, Choi SY, Baik SO, Kim CS. The Hepatoprotective Effect of Acanthopanax senticosus Fermentation Products in Fatty Liver Model. J Korean Soc Food Sci Nutr. 2014;43(1):40-6. 
Journal of Korean Medicine 2018;39(4)

\section{ORCID}

Ah-Ra Cho https://orcid.org/0000-0002-1122-0725

San Seo https://orcid.org/0000-0001-5978-3546

Yoon-Hong Yang https://orcid.org/0000-0002-3664-4049

A-Rin Lee https://orcid.org/0000-0003-2938-2068

Hyung-Tak Lee https://orcid.org/0000-0002-0046-5268 